\title{
Vitamin C in fleshy fruits: biosynthesis, recycling, genes, and enzymes
}

\author{
D.Y. Tyapkina ${ }^{1}$, E.Z. Kochieva ${ }^{1,2}$, M.A. Slugina ${ }^{1,2} \otimes$ \\ ${ }^{1}$ Institute of Bioengineering, Research Center of Biotechnology, RAS, Moscow, Russia \\ ${ }^{2}$ Lomonosov Moscow State University, Moscow, Russia \\ 凶e-mail:mashinmail@mail.ru
}

\begin{abstract}
L-ascorbic acid (vitamin C) is a plant secondary metabolite that has a variety of functions both in plant tissues and in the human body. Plants are the main source of vitamin $C$ in human nutrition, especially citrus, rose hip, tomato, strawberry, pepper, papaya, kiwi, and currant fruits. However, in spite of the biological significance of L-ascorbic acid, the pathways of its biosynthesis in plants were fully understood only in 2007 by the example of a model plant Arabidopsis thaliana. In the present review, the main biosynthetic pathways of vitamin $C$ are described: the L-galactose pathway, L-gulose pathway, galacturonic and myo-inositol pathway. To date, the best studied is the L-galactose pathway (Smyrnoff-Wheeler pathway). Only for this pathway all the enzymes and the entire cascade of reactions have been described. For other pathways, only hypothetical metabolites are proposed and not all the catalyzing enzymes have been identified. The key genes participating in ascorbic acid biosynthesis and accumulation in fleshy fruits are highlighted. Among them are L-galactose pathway proteins (GDP-mannose phosphorylase (GMP, VTC1), GDP-D-mannose epimerase (GME), GDP-L-galactose phosphorylase (GGP, VTC2/VTC5), L-galactose-1-phosphate phosphatase (GPP/VTC4), L-galactose-1-dehydrogenase (GalDH), and L-galactono1,4-lactone dehydrogenase (GalLDH)); D-galacturonic pathway enzymes (NADPH-dependent D-galacturonate reductase (GalUR)); and proteins, controlling the recycling of ascorbic acid (dehydroascorbate reductase (DHAR1) and monodehydroascorbate reductase (MDHAR)). Until now, there is no clear and unequivocal evidence for the existence of one predominant pathway of vitamin C biosynthesis in fleshy fruits. For example, the L-galactose pathway is predominant in peach and kiwi fruits, whereas the D-galacturonic pathway seems to be the most essential in grape and strawberry fruits. However, in some plants, such as citrus and tomato fruits, there is a switch between different pathways during ripening. It is noted that the final ascorbic acid content in fruits depends not only on biosynthesis but also on the rate of its oxidation and recirculation.
\end{abstract} Key words: L-ascorbic acid; vitamin C; fruits; metabolism; the key genes of ascorbic acid biosynthesis.

For citation: Tyapkina D.Y., Kochieva E.Z., Slugina M.A. Vitamin C in fleshy fruits: biosynthesis, recycling, genes, and enzymes. Vavilovskii Zhurnal Genetiki i Selektsii = Vavilov Journal of Genetics and Breeding. 2019;23(3):270-280. DOI 10.18699/VJ19.492

\section{Накопление витамина С в сочных плодах: биосинтез и рециркуляция, гены и ферменты}

\author{
А.Ю. Тяпкина ${ }^{1}$, Е.3. Кочиева ${ }^{1,2}$, М.А. Скугина ${ }^{1,2}$ ه \\ ${ }^{1}$ Институт биоинженерии Федерального исследовательского центра «Фундаментальные основы биотехнологии» Российской академии наук, \\ Москва, Россия \\ ${ }^{2}$ Московский государственный университет им. М.В. Ломоносова, Москва, Россия \\ 凶e-mail: mashinmail@mail.ru
}

L-аскорбиновая кислота (витамин C) - вторичный метаболит растений, выполняющий множество разнообразных функций как в растительных тканях, так и в организме человека. Основным источником витамина $C$ в питании человека служат растения, и прежде всего плоды цитрусовых, шиповника, перца, смородины, томата, клубники, папайи, киви. Однако, несмотря на то что L-аскорбиновая кислота - важное биологически активное вещество, путь ее биосинтеза в растительной клетке был описан лишь в 2007 г. на примере модельного растения Arabidopsis thaliana. В настоящем обзоре рассмотрены известные на сегодняшний день пути биосинтеза L-аскорбиновой кислоты в тканях растений. Это L-галактозный, L-гулозный, галактуроновый и мио-инозитоловый пути. Наиболее изучен из них L-галактозный путь (путь Смирнова-Уилера), для которого определены все ферменты, катализирующие последовательную цепь реакций. Для других путей известна лишь предположительная последовательность метаболитов, при этом многие ферменты, катализирующие их превращение, еще не выявлены. Выделены ключевые гены, которые участвуют в биосинтезе и накоплении аскорбиновой кислоты в сочных плодах. Среди них ферменты L-галактозного пути (ГДФ-маннозофосфорилаза (GMP, VTC1), ГДФ-D-маннозо-3'5'-эпимераза (GME), ГДФ-L-галактозофосфорилаза (GGP, VTC2/VTC5), L-галактозо-1-фосфатфосфатаза (GPP/VTC4), L-галактозо-1-дегидрогеназа (GalDH) и L-галактоно1,4-лактондегидрогеназа (GalLDH)); ферменты D-галактуронового пути (NADPH-зависимая D-галактуронатредуктаза (GalUR)) и ферменты рециркуляции AK (дегидроаскорбатредуктаза (DHAR1) и монодегидро- 
аскорбатредуктаза (MDHAR)). До сих пор нет однозначного описания всех путей биосинтеза и накопления L-аскорбиновой кислоты в плодах. B настоящее время нельзя однозначно утверждать, что какой-то из четырех известных путей биосинтеза аскорбиновой кислоты является преобладающим в плодах растений. Так, в плодах персика и киви основным является L-галактозный путь, тогда как в плодах винограда и клубники - по всей видимости, D-галактуроновый. В то же время у ряда растений, например цитрусовых или томата, по мере созревания плодов может происходить смена различных путей биосинтеза. Отмечается, что уровни накопления аскорбиновой кислоты зависят не только от биосинтеза, но и от скорости ее окисления и рециркуляции.

Ключевые слова: L-аскорбиновая кислота; витамин C; плоды; метаболизм; гены биосинтеза аскорбиновой кислоты.

\section{Introduction}

L-Ascorbic acid (vitamin C) is a secondary plant metabolite involved in manifold functions in the cell (Davey et al., 2000; Iqbal et al., 2009; Smirnoff, 2018). L-Ascorbic acid (L-AsA) acts as an expression regulator for many genes, influences plant growth and development via phytohormones, and, which is no less important, is involved in the plant cell response to the impact of biotic and abiotic stress factors (Pastori et al., 2003; Gest et al., 2013; Li et al., 2013). Some plant species utilize ascorbates as a substrate for biosynthesis of other important metabolites, for example, oxalates and tartrates (Loewus F.A., Loewus M.W., 1987; Loewus F.A., 1999; Cruz-Rus et al., 2010).

Vitamin C is especially valuable in human diet since humans and other higher primates had lost the ability to produce L-AsA because of a mutation in one of the enzymes involved in its biosynthesis (Nishikimi, Yagi, 1996). Vitamin C plays an important role in the normal functioning of the body, being a coenzyme in several metabolic processes. It also possesses antioxidant properties and eliminates free radicals, which contribute to carcinogenesis and body aging (FigueroaMéndez, Rivas-Arancibia, 2015). In addition, vitamin $\mathrm{C}$ improves human immunity by activating phagocytes, prevents the cardiovascular diseases associated with atherosclerosis, and enhances collagen formation and development of the cartilage tissue (Diplock et al., 1998). The main source of this vitamin in human diet is plants; fruits of citruses, sweet-brier, actinidia (kiwi), sand thorn, papaya, strawberry, mountain ash, sweet pepper, and tomato display the highest content of vitamin C (Iqbal et al., 2009; Streltsina et al., 2010).

\section{Biosynthesis of ascorbic acid in plant cell}

Strange it may seem but the biosynthesis of L-AsA in plant cell was finally described in a model plant, Arabidopsis thaliana, only as late as 2007 (Linster et al., 2007) despite its evident importance in the life of plants and human health. Unlike animals, which synthesize L-AsA from glucuronic acid, the plant cell has at least four alternative pathways of its biosynthesis, namely, L-galactose, L-gulose, galacturonic, and myo-inositol pathways (see the Figure) (Li et al., 2010; Yang et al., 2011).

\section{L-Galactose pathway}

The L-galactose pathway, or Smirnoff-Wheeler pathway (Wheeler et al., 1998), is currently regarded as the main pathway of L-AsA biosynthesis in plants. The initial substrate for this pathway is a glucose molecule. The Smirnoff-Wheeler pathway comprises 10 successive stages. Interestingly, the first eight stages transform D-glucose into L-galactose, which differs from D-glucose only by the spatial positions of hydrogen and hydroxyl groups at the fourth carbon atom (Linster et al., 2007).

GDP-D-mannose and GDP-L-galactose are important metabolites of this pathway. The enzyme GDP-D-mannose-3',5'epimerase controls their mutual transformation. It is important here that the main part of the products in this reaction is spent for the primary metabolic reactions, namely, the biosynthesis of cell wall polysaccharides (Roberts, 1971; Baydoun, Fry, 1988), which is maximally active in growing organs and tissues. This suggests that the initial stages of this metabolic pathway are mainly involved in the growth of organs (leaves, fruits, and so on). In the formed (mature) organs, the secondary metabolic reactions are switched on and provide further transformation of GDP-L-galactose to AsA. Therefore, the limiting stage in this metabolic pathway of vitamin $\mathrm{C}$ synthesis is the reaction that directly generates L-AsA and is controlled by the enzyme GDP-L-galactose phosphorylase, VTC2 (see the Figure). It is believed that VTC2 is of a key importance for production of vitamin $\mathrm{C}$ and that its activity depends on the need of a cell in synthesizing cell wall polysaccharides (Bulley et al., 2012; Wang et al., 2014).

\section{L-Gulose pathway}

The case study of arabidopsis has shown that one of the enzymes of the above briefed pathway, GDP-D-mannose-3', 5'epimerase (GME), putatively possesses 5'-isomerase activity and is able to catalyze GDP-D-mannose transformation to GDP-L-gulose (Wolucka, Van Montagu, 2003) along with the 3',5'-isomerase activity, converting GDP-D-mannose to GDP-L-galactose. The next assumption was that GDP-Lgulose in the course of subsequent transformation into Lgulose-1-phosphate, L-gulose, and L-gulono-1,4-lactone could be also converted to L-AsA (see the Figure). However, the corresponding catalytic enzymes of the L-gulose pathway of vitamin $\mathrm{C}$ synthesis in plants have not been yet discovered except for L-gulono-1,4-lactone oxidase of arabidopsis (Maruta et al., 2010). Interestingly, the overexpression of rat L-gulono-1,4-lactone oxidase $(A L O)$ elevated the L-ascorbic acid content in tobacco and lettuce (Jain, Nessler, 2000). An overexpression of rat $A L O$ in the arabidopsis plants carrying a mutation in $V T C$ gene (deficient in vitamin C) completely restored the L-AsA level (Radzio et al., 2003). This suggests that the L-gulose pathway may be regarded as one of the alternative pathways in L-AsA biosynthesis in plants. 


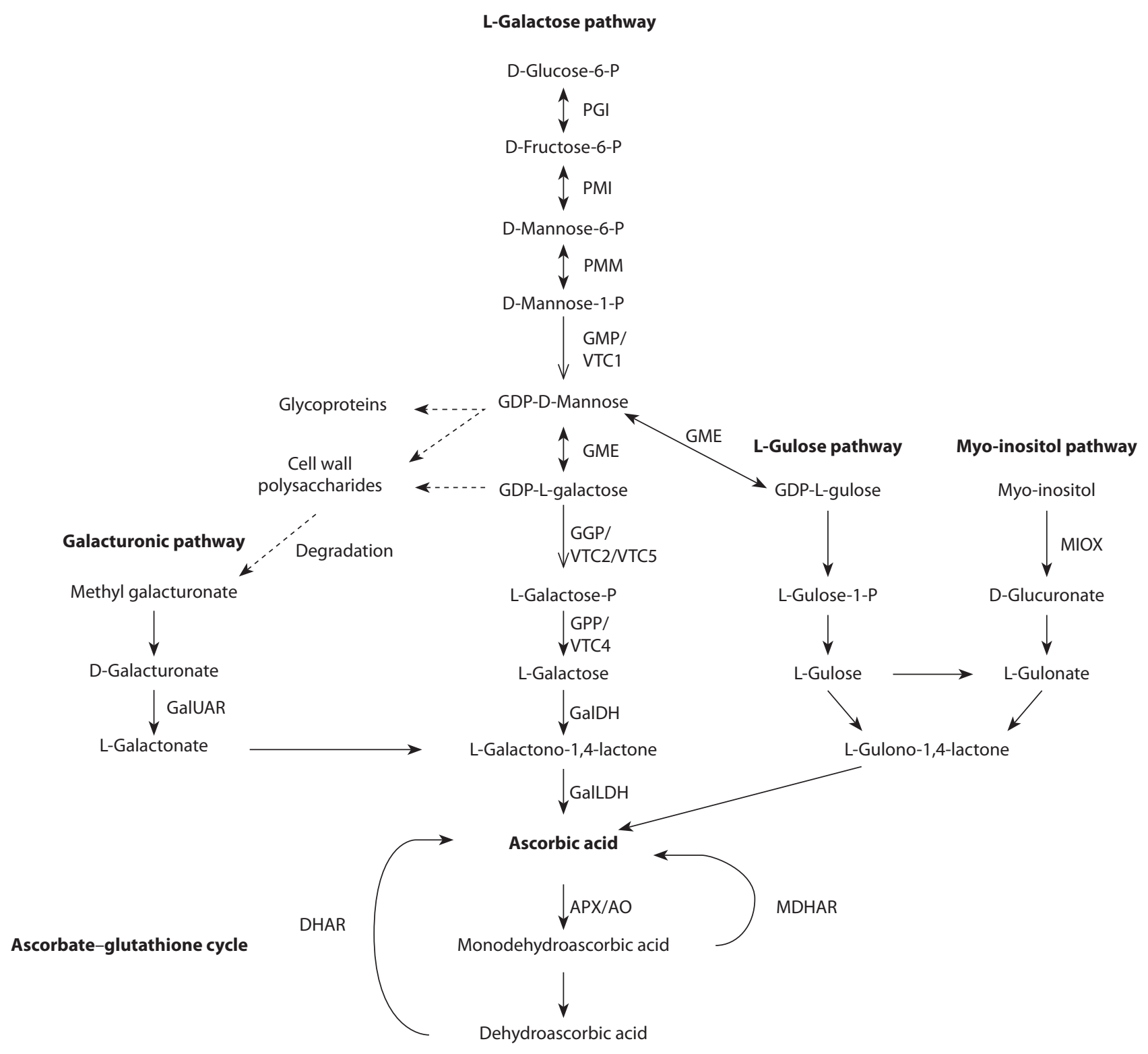

Pathways of L-AsA biosynthesis in plant cells, according to (Li et al., 2010; Suekawa et al., 2017) with some modifications.

\section{Myo-inositol pathway}

Myo-inositol is a carbohydrate metabolite synthesized by most cells and necessary for a normal plant growth and development. In a form of inositol phosphates and phosphatidylinositol lipids, myo-inositol is involved in intracellular signal transduction in various cascades (Michell, 2007).

The myo-inositol pathway of L-AsA biosynthesis in plants comprises four stages (see the Figure). Myo-inositol is oxidized by myo-inositol oxygenase to D-glucuronic acid, which is further converted by glucuronate reductase to L-gulonic acid with subsequent transformation to L-gulono-1,4-lactone, which is catalyzed by aldonolactonase. The last reaction in this line is the transformation of L-gulono-1,4-lactone to L-AsA, catalyzed by L-gulonolactone dehydrogenase (Lorence et al., 2004).

Myo-inositol oxygenase (MIOX) is the key enzyme in this pathway: it is shown by the case study of arabidopsis that an overexpression of MIOX doubles the vitamin $\mathrm{C}$ content in flowers and leaves (Lorence et al., 2004). The remaining enzymes involved in the subsequent reactions in plants are still not determined.

\section{D-Galacturonic pathway}

As was shown in the early 1960s, galacturonic acid methyl ester is convertible to L-AsA. The existence of this metabolic pathway was for the first time demonstrated in the case study of a protist, Euglena gracilis (Shigeoka et al., 1979). In plants, exogenous application of D-galacturonic acid methyl ester elevates the ascorbic acid content in different tissues and arabidopsis cell culture (Loewus, Kelly, 1961; Davey et al., 1999), thereby demonstrating the presence of this pathway of ascorbic acid biosynthesis.

Note that the initial substrates for the D-galacturonic pathway are the degradation products of cell wall polysac- 
charides. D-Galacturonic acid is a necessary player in two concurrent biochemical processes - synthesis of pectins, an important cell wall component, and AsA biosynthesis. According to the current view, this pathway comprises several key enzyme-catalyzed stages providing the reduction of D-galacturonic acid to L-galactonic acid or L-galactono-1,4lactone by galacturonate reductase and subsequent formation of L-AsA (see the Figure). An important role of this metabolic pathway has been demonstrated for the fruits of several plants, such as the strawberry (Agius et al., 2003), grape (Cruz-Rus et al., 2010), orange (Xu et al., 2013), and apple (Mellidou et al., 2012). Since the D-galacturonic pathway is considerably shorter as compared with the L-galactose one, which is regarded the main pathway of AsA biosynthesis, it is assumed that the former may well supplement the prevalent biosynthesis pathway in fruits under stress conditions (CruzRus et al., 2011).

\section{AsA recycling (ascorbate-glutathione cycle)}

The current data volume accumulated while studying the AsA metabolism in plant cells suggests that the AsA levels depend not only on its biosynthesis, but also on it oxidation and further recycling (Li et al., 2013).

The L-AsA formed in one of the above described biosynthesis cycles acts in the plant cell as an antioxidant, protecting from oxidative stress (Akram et al., 2017). In these processes, oxidized forms (monodehydroascorbic and dehydroascorbic acids) are formed. During the recycling, the oxidized forms are again reduced to AsA with the help of two reductases - monodehydroascorbate reductase (MDHAR) and dehydroascorbate reductase (DHAR). This is known as the ascorbate-glutathione cycle (see the Figure). The biological function of this cycle is determined by that the cell contains reactive oxygen species, on the one hand, and AsA has antioxidant properties, on the other.

The first stage in this pathway is detoxification of reactive oxygen species with the help of ascorbate peroxidase (APX) or ascorbate oxidase (AO). This gives monodehydroascorbic acid, which is either again reduced to AsA by MDHAR, or dehydroascorbic acid, which is reduced by DHAR.

Thus, the AsA final content in plant organs and tissues depends on both its biosynthesis and recycling.

\section{Specific features of AsA biosynthesis and accumulation in fruits}

L-AsA is involved in manifold functions in the life of a plant organism. The AsA biosynthesis is triggered in response to various endogenous and exogenous impacts and takes place in almost all plant tissues and organs. Therefore, the presence of at least four pathways for AsA synthesis is not surprising as well as switching between these pathways depending on the particular demands and conditions in the cell. However, our interest is naturally focused on how vitamin $\mathrm{C}$ is accumulated in edible parts of the plants; correspondingly, it is necessary to clearly understand which metabolic pathway of AsA biosynthesis is major in the fruits of different plant species. Although this issue is of considerable importance, the studies on the specific features of the vitamin $\mathrm{C}$ accumulation in plant fruits are few. Currently, the pathways of AsA biosynthesis and accumulation in fruits have been examined in sufficient detail in some cultivated plants, such as the strawberry, tomato, grape, kiwi, apple, pear, sweet cherry, and citruses (Agius et al., 2003; Hancock et al., 2007; Bulley et al., 2009; Cruz-Rus et al., 2010; Di Matteo et al., 2010; Li et al., 2010; Walker et al., 2010; Badejo et al., 2012; Alós et al., 2014).

As a rule, AsA is gradually accumulated with an increase in the mass of the developing fruit with the highest rate on days 75-100 after anthesis. This pattern of AsA accumulation has been observed, for example, for the tomato (Ioannidi et al., 2009). However, AsA more rapidly accumulates at early stages of fruit development in kiwi (Bulley et al., 2009) and black currant (Hancock et al., 2007) fruits, when the cell biosynthetic activity is maximal (Li et al., 2011).

A significant role of the major (L-galactose) pathway has been shown for several species. In particular, it has been shown that the content of vitamin $\mathrm{C}$ in the black currant (Ribes nigrum) fruits considerably varies depending on both climatic conditions and genotype; note that the correlation of expression with vitamin $\mathrm{C}$ accumulation is shown for only one gene, the gene coding for GDP-D-mannose-3'5'-epimerase (Walker et al., 2010).

The maximum content of vitamin $\mathrm{C}$ in kiwi (Actinidia deliciosa variety Qinmei) fruits is observable on day 30 after anthesis with a gradual decrease by day 60. Expression patterns are similar for most of the studied key genes except for the genes encoding L-galactono-1,4-lactone dehydrogenase $(G a l L D H)$ and L-galactose-1-phosphate phosphatase (GPP/ VTC4). Note that only GPP expression correlates with AsA accumulation (Li et al., 2010).

An important role of the enzymes involved in the D-galacturonic pathway has been also demonstrated for the content of vitamin C in tomato (Solanum lycopersicum) fruits, typically reaching $35 \mathrm{mg}$ per $100 \mathrm{~g}$. Moreover, an increase in AsA with tomato (cultivar Micro-Tom) fruit ripening is inversely correlated with the expression of the genes involved in the major (L-galactose) pathway (Badejo et al., 2012). The L-galactose and D-galactouronate treatment of tomato plants increased the vitamin $\mathrm{C}$ content in the mature fruits; however, this result was unachievable by treating the plants with L-gulono-1,4lactone, formed in the L-gulose and myo-inositol pathways (see the Figure) (Badejo et al., 2012). This suggests that the AsA synthesis during tomato fruit ripening may start with the Smirnoff-Wheeler pathway to further switch to the Dgalacturonic pathway, the enzymes of which work at the late stage of fruit ripening. D-Galacturonic acid is produced via the cleavage of cell wall pectin; this suggests that the pathway in question is activated during the maceration of tomato fruits (Badejo et al., 2012). As has been earlier demonstrated, expression of the genes coding for pectinesterases and polygalacturonases (the enzymes involved in pectin degradation) is very high in an introgression line, IL 12-4 (S. pennellii and S. lycopersicum), differing from the parental line by a considerably higher vitamin $\mathrm{C}$ content. This is another evidence for that the D-galacturonic pathway is directly involved in the accumulation of vitamin $\mathrm{C}$ in tomato fruits (Di Matteo et al., 2010).

AsA is a most valuable component in the grapes (Vitis vinifera), acting as the substrate for synthesis of tartaric acid (Cholet et al., 2016). Similar to the strawberry and tomato fruits, the AsA content increases with grape ripening reaching 
its maximum in fully mature fruits. Expression analysis of the genes controlling different AsA biosynthesis pathways in grape fruits demonstrates a strong correlation of the transcription of D-galactouronate reductase gene (GalUR) and the quantitative content of vitamin $\mathrm{C}$ (Cruz-Rus et al., 2010). Thus, the D-galacturonic pathway is also regarded as a major pathway for vitamin $\mathrm{C}$ biosynthesis during grape fruit development and ripening (Cruz-Rus et al., 2010).

It is known that the mature strawberries (Fragaria sp.) are rich in vitamin $\mathrm{C}$, containing on the average $60 \mathrm{mg}$ AsA per $100 \mathrm{~g}$ fresh tissue (Agius et al., 2003). As is shown, the D-galacturonic pathway is significant for the AsA accumulation in strawberry fruits. Expression of one of the enzymes of this pathway, NADPH-dependent D-galacturonate reductase (GalUR), in strawberry fruits increases proportionally to the accumulation of vitamin $\mathrm{C}$ there. Overexpression of the strawberry GalUR gene in arabidopsis leaves gives a twofold increase in vitamin $\mathrm{C}$ content there, suggesting an important role of this particular enzyme in AsA biosynthesis (Agius et al., 2003).

Note that the final vitamin $\mathrm{C}$ content in fruits depends not only on the rate of AsA biosynthesis, but also on its recycling (see the Figure). In particular, it has been shown that the expression of MDHAR gene (ascorbate-glutathione pathway) in strawberries positively correlates with the accumulation of vitamin C in developing fruits (Cruz-Rus et al., 2011).

The maximum AsA content in sweet cherry (Prunus avium cultivar Hongdeng) fruits is observed during their setting followed by a gradual decrease during fruit development and a moderate increase in the mature fruit (Liang et al., 2017). Nonetheless, AsA content continues to increase with the weight of fresh fruits. Full-sized cDNAs of 10 genes involved in the L-galactose pathway of AsA biosynthesis have been described as well as of 10 genes involved in AsA recycling. The expression levels of the genes encoding GDPL-galactose phosphorylase (GGP2), L-galactono-1,4-lactone dehydrogenase $(\mathrm{GalLDH})$, ascorbate peroxidase (APX3), ascorbate oxidase (AO2), glutathione reductase $(G R 1)$, and dehydroascorbate reductase (DHAR1) correlate with the quantitative content of vitamin $\mathrm{C}$ during fruit development, which suggests that the joint work of all these genes involved in AsA biosynthesis, degradation, and recycling together regulates the AsA accumulation in sweet cherry fruits (Liang et al., 2017).

The enzymatic activities involved in the AsA biosynthesis via the Smirnoff-Wheeler pathway and its recycling in different fruit tissues have been comprehensively studied in pear (Pyrus pyrifolia cultivar Aikansui) fruits (Huang et al., 2013). Biochemical analysis demonstrates that the AsA content increases with fruit development to reach the maximum 30 days after anthesis and then decreases and is maintained at the same level. The highest AsA concentration is observed in the pear peel, which is a result of a high L-galactose dehydrogenase and L-galactono-1,4- lactone dehydrogenase activities, on the one hand, and dehydroascorbate reductase and monodehydroascorbate reductase (involved in AsA recycling), on the other. An exogenous application of the precursors of AsA biosynthesis has shown that the peel displays a higher ability to synthesize the target substance via the Smirnoff-Wheeler and D-galacturonic pathways, whereas the pulp and core were less capable of synthesizing AsA (Huang et al., 2013).

According to a study of apple (Malus domestica) fruits, AsA can be synthesized via the L-galactose pathway (Li et al., 2008). Further studies of the dynamics of vitamin $\mathrm{C}$ accumulation during fruit (cultivar Gala) ripening have shown that the transcription levels of the genes coding for GDP-L-galactose phosphorylase, GDP-L-mannose pyrophosphorylase, D-galacturonate reductase, and L-galactono-1,4-lactone dehydrogenase, regulated on a posttranscriptional level, do not correlate with vitamin $\mathrm{C}$ accumulation. On the other hand, the expression patterns of L-galactose dehydrogenase, L-galactose-1-phosphate phosphatase, and GDP-D-mannose$3^{\prime} 5$ '-epimerase are in general similar to the AsA accumulation pattern. Interestingly, the expression and activity of the genes of monodehydroascorbate reductase and dehydroascorbate reductase, which degrade AsA in fruits, do not correlate with the AsA accumulation during fruit development (Li et al., 2011).

In addition, the search for the quantitative trait loci (QTL) responsible for the vitamin $\mathrm{C}$ accumulation in the M. domestica fruits (Mellidou et al., 2012) has succeeded in finding a linkage group that comprises the genes of GDPL-galactose phosphorylase $(G G P)$ and dehydroascorbate reductase $(D H A R)$. Of special interest are three $G G P$ paralogous genes, all residing within the AsA-QTL cluster. The association between some allelic variants of the GGP gene and increased vitamin $\mathrm{C}$ content has been observed. Comparison of the GGP expression patterns in the specimens displaying high and low vitamin $\mathrm{C}$ contents suggests a key role of $G G P$ in the accumulation of vitamin C. Molecular markers (SNPs) have been found; these markers are helpful when breeding new cultivars with an increased vitamin $\mathrm{C}$ content in apple fruits (Mellidou et al., 2012). In addition, a correlation between DHAR and a QTL associated with the resistance to flesh browning has been shown (Mellidou et al., 2012).

Citruses are known as an important source of vitamin $\mathrm{C}$. Expression patterns of 13 genes involved in vitamin $\mathrm{C}$ metabolism (including its synthesis, degradation, and recycling) in two citrus fruits - orange (Citrus sinensis) and tangerine ( $C$. unshiu) - have been studied. The L-galactose pathway is shown to be major for the synthesis of vitamin C. Note that AsA accumulation is maximum in the peel and pulp, correlating with the expression profiles of the genes involved in the L-galactose pathway, whereas the myo-inositol pathway is prevalent for the AsA synthesis in immature fruit peel. $G G P$ and $G P P$ are regarded as the key genes controlling the AsA synthesis in the pulp; as for the peel, the function of GMP and MIOX is also important (Alós et al., 2014). In addition, a relative expression of the MDHAR and $D H A R$ genes (involved in recycling) correlates with the AsA accumulation during fruit ripening and the cultivars with an elevated AsA content displayed an upregulation of these genes (Alós et al., 2014).

Thus, it is currently impossible to unambiguously state which of the four known pathways of AsA biosynthesis is prevalent in plant fruits. In particular, the L-galactose pathway is prevalent in peach (Imai et al., 2009) and kiwi (Bulley et al., 2009) versus grapes (Cruz-Rus et al., 2010) and strawberries (Agius et al., 2003), where the L-galacturonic pathway is 
likely to be prevalent. On the other hand, the prevalence of AsA pathways changes during fruit ripening in several plants, for example, citruses, or tomatoes (Bajero et al., 2012; Alós et al., 2013).

\section{Key enzymes determining L-AsA biosynthesis and accumulation in berries, vegetables, and fruits}

\section{Enzymes of L-galactose pathway}

GDP-mannose phosphorylase (GMP or VTC1), EC 2.7.7.22, displays a mannose-1-phosphate guanylyltransferase activity. The gene coding for this enzyme was for the first time detected in and cloned from a mutant arabidopsis plant with a decreased AsA content (Conklin et al., 1999). As has been later shown, an inhibition of GMP in the tomato decreases the AsA content in fruits (Keller et al., 1999).

The NCBI database contains VTC1 gene sequences of the arabidopsis (A. thaliana), tomato ( $S$. lycopersicum), turnip (Brassica rapa), cabbage (B. oleracea), potato (Solanum tuberosum), papaya (Carica papaya), sweet cherry (P. avium), rice (Oryza sativa), tobacco (Nicotiana tabacum), jujube (Ziziphus jujuba), and pepper (Capsicum annuum). The gene with a total length of approximately $2500 \mathrm{bp}$ is rather conserved in its structure, comprising four exons and four introns.

GDP-D-mannose-3'5'-epimerase (GME), EC 5.1.3.18, catalyzes the reversible epimerization of GDP-D-mannose, which is among the main reactions in the L-galactose pathway of AsA biosynthesis. In this reaction, a high-energy glycosyl-pyrophosphoryl linkage is hydrolyzed. GME is able to catalyze two different reactions with formation of either GDP-L-galactose or GDP-L-gulose from GDP-D-mannose. GDP-L-gulose is the initial substrate for the alternative gulose pathway of AsA biosynthesis. The other reaction product, GDP-L-galactose, can be further utilized not only for synthesizing vitamin $\mathrm{C}$, but also in biosynthesis of the cell wall and glycoproteins, which is primarily necessary for the development of vegetative organs (Lukowitz et al., 2001; Gilbert et al., 2009; Mounet-Gilbert et al., 2016). As has been shown, this enzyme activity can also influence pollen development and seed formation (Mounet-Gilbert et al., 2016).

Currently, GME is regarded as one of the most important enzymes in the L-AsA biosynthesis in plants. The genes coding for this enzyme have been isolated and characterized in the arabidopsis (Wolucka et al., 2001; Wolucka, Van Montagu, 2003), rice (Watanabe et al., 2006), and tomato (Zhang C.J. et al., 2011; Zhang Y.Y. et al., 2011). Interestingly, the rice and tomato genomes carry two paralogous genes each (Watanabe et al., 2006; Zhang C.J. et al., 2011; Zhang Y.Y. et al., 2011). A positive correlation between expression of this gene and AsA content is observed in the apple (Li et al., 2010) and blueberry (Liu et al., 2015). However, this pattern is unobservable in the kiwi (Bulley et al., 2009), peach (Imai et al., 2009), and tomato (Ioannidi et al., 2009; Mellidou et al., 2012). Taking into account the need in maintenance of the metabolic balance between the syntheses of AsA and cell wall, competing for the common substrate (GDP-L-galactose), it is shown that an overexpression of the GME gene does not lead to an increase in the AsA content in arabidopsis (Yoshimura et al., 2014). On the other hand, a joint overexpression of GME and the gene coding for the enzyme catalyzing the limiting stage of the L-galactose pathway, $G P P$, results in a considerably increase AsA accumulation as compared with the overexpression of GPP alone (Bulley et al., 2009). Analogous data have been also obtained for kiwi fruits (Bulley et al., 2009). This demonstrates a highest importance of the GME and GPP genes and their joint control in the L-galactose pathway.

In plants, two paralogous genes are known, GME1 and $G M E 2$. These genes have a length of approximately $1500 \mathrm{bp}$, display a high homology, and consist of six exons and five introns. Among the horticultural crops, these genes are known in the grape vine ( $V$. vinifera), tomato ( $S$. lycopersicum), pineapple (Ananas comosus), melon (Cucumis melo), and mulberry (Morus notabilis).

GDP-L-galactose phosphorylase (GGP or VTC2/VTC5), EC 2.7.7.69, catalyzes the GDP-L-galactose phosphorylation to L-galactose-1-phosphate. An important role of the VTC2 gene was demonstrated in the arabidopsis (Dowdle et al., 2007). The recombinant VTC2 alleles of the wild-type arabidopsis and two mutants were expressed in Escherichia coli. The product of one mutant allele did not lead to vitamin C synthesis and the product of the other mutant allele displayed only $2 \%$ of the total wild-type VTC2 activity. However, a comprehensive analysis of the plants has shown that the $v t c 2$ mutants of arabidopsis still accumulated AsA at the level of $10-20 \%$ of its content in wild-type plants. This suggested existence of certain other pathways of AsA biosynthesis (Dowdle et al., 2007; Laing et al., 2007; Linster et al., 2007, 2008).

In addition, the changes in AsA level in response to the $V T C 2$ overexpression in arabidopsis, tomato, strawberry, potato, and rice have been experimentally studied (Bulley et al., 2012; Wang et al., 2014). The plants transformed with the constructs carrying VTC2 gene displayed a considerable increase in the AsA content (Bulley et al., 2012; Wang et al., 2014).

Certain data demonstrate that not only the coding sequence of VTC2 gene, but also a region in its promoter sequence influences the AsA accumulation in fruits. As has been shown, the AsA biosynthesis may be controlled via a posttranscriptional repression of GDP-L-galactose phosphorylase. This regulation involves an additional reading frame (uORF). Its "switchoff" leads to the synthesis of GDP-L-phosphorylase and, as a consequence, to an increase in the AsA concentration. This posttranslational AsA regulation is most likely a rather ancient control mechanism, since the uORF is retained in GGP genes from the mosses to angiosperms (Laing et al., 2015).

All this suggests that $G G P / V T C 2$ in some plants is the key regulator of AsA biosynthesis; many biotechnological studies aimed at an increase in the vitamin $\mathrm{C}$ content have been performed utilizing this particular gene (Zhou et al., 2012).

So far, the NCBI database contains the sequence of several GGP paralogs from the arabidopsis (A. thaliana), turnip (B. rapa), field mustard (Brassica arvensis), cabbage (B. oleracea), maize (Zea mays), sunflower (Helianthus annuus), potato (S. tuberosum), and tobacco (N. attenuata). The lengths of these DNAs vary around $2740 \mathrm{bp}$ and they comprise seven exons and six introns.

L-galactose-1-phosphate phosphatase (GPP/VTC4), EC 3.1.3.B9, catalyzes dephosphorylation with formation of L-galactose. GPP is also regarded as an efficient enzyme for 
regulation of AsA synthesis. This was first assumed for kiwi fruits (Laing et al., 2004; Bulley et al., 2009), apple (Mellidou et al., 2012), and tomato (Ioannidi et al., 2009). However, note that AsA is synthesized even in the case of GPP gene knockout although in a smaller quantity, which suggests that either there are other functional phosphatases involved in AsA biosynthesis or AsA is synthesized via other pathways (Conklin et al., 2006; Torabinejad et al., 2009).

It has been shown that GPP is a bifunctional enzyme able to catalyze the biosynthesis not only of AsA, but also of myo-inositol. Thus, GPP activity may represent the junction point of the L-galactose and myo-inositol pathways of AsA biosynthesis (Torabinejad et al., 2009).

Homologous GPP genes comprising 12 exons and 11 introns in the arabidopsis (length, $2413 \mathrm{bp}$ ) and nine exons and nine introns in turnip (length, $7196 \mathrm{bp}$ ) are known in the kingdom of plants.

L-galactose-1-dehydrogenase (GaIDH), EC 1.1.1.316, and L-galactono-1,4-lactone dehydrogenase (GalLDH), EC 1.3.2.3. GalDH oxidizes L-galactose to L-galactono-1,4lactone using $\mathrm{NAD}^{+}$as electron acceptor. GalLDH is the final enzyme of the L-galactose pathway and directly leads to AsA synthesis. So far, the GalLDH gene has been isolated from the arabidopsis, pea, kiwi, and apple (Gatzek et al., 2002; Laing et al., 2004; Mieda et al., 2004). As has been shown for pear fruits, a high AsA concentration in the peel is in part determined by high activities of GalDH and the next enzyme in the biosynthesis pathway, GalLDH (Huang et al., 2013). GalLDH has been characterized for several plant species, including the sweet potato (Imai et al., 1998), cauliflower (Oesterhelt et al., 1997), spinach (Mutsuda et al., 1995), tobacco (Yabuta et al., 2000), strawberry (do Nascimento et al., 2005), melon (Pateraki et al., 2004), tomato (Zhang C.J. et al., 2011; Zhang Y.Y. et al., 2011), and arabidopsis (Leferink et al., 2008). Before the discovery of VTC2, it was believed that these particular enzymes, involved in the final stages of AsA biosynthesis, could play the key role in at least tomatoes (Alhagdow et al., 2007; Mellidou et al., 2012). However, GalDH has been recently assumed to influence AsA accumulation being involved in the AsA transport between different organs (Mellidou, Kanellis, 2017; Rodríguez-Ruiz et al., 2017).

Homologs of the GalDH gene have been found in the genomes of maize (Z. mays), sweet cherry (P. avium), barley (Hordeum vulgare), and arabidopsis (A. thaliana). This gene on the average is $4300 \mathrm{bp}$ long and comprises five exons and four introns. As for the homologs of the GalLDH gene, they have been annotated in the genomes of sweet cherry (P. avium), sweet pepper ( $C$. annuum), and apple ( $M$. domestica); have lengths of 5139, 7667, and 6329 bp, respectively; and comprise six exons and five introns.

\section{Enzymes of D-galacturonic pathway}

NADPH-dependent D-galacturonate reductase (GalUR). The substrate for this enzyme is D-galacturonate, which is the product of degradation of cell wall pectins; the GalURcatalyzed reaction gives L-galactonate (see the Figure). As is shown, the GalUR expression in grape ( $V$. vinifera) fruits correlates with the vitamin $\mathrm{C}$ accumulation during fruit ripening (Cruz-Rus et al., 2010); analogous pattern is observed in the strawberry (Agius et al., 2003) as well as the key role of this enzyme in the AsA biosynthesis. Note that the reactions of the D-galacturonic pathway in plants are yet insufficiently studied and require further biochemical, physiological, and genetic studies. Homologs of the GalUR gene have been annotated in the genomes of the sunflower (H. annuus) and tobacco (N. attenuata); their lengths are 2671 and $12453 \mathrm{bp}$, respectively; and they comprise four exons and three introns.

\section{Enzymes involved in AsA recycling}

Dehydroascorbate reductase (DHAR1) and monodehydroascorbate reductase (MDHAR). MDHAR enzyme activity is tightly correlated with the AsA accumulation in tomatoes at a decreased temperature, suggesting its significant role in the regulation of AsA synthesis under stress.

Identification of the MDHAR and DHAR genes and their further functional analysis have shown that an overexpression of the DHAR gene provides a 1.6-fold increase in the AsA content in the tomato fruits grown at a relatively low illumination. A study of expression levels of two MDHAR isoforms demonstrates that an increase in the transcription of this gene is negatively correlated with an increase in the AsA level during tomato fruit ripening (Li et al., 2013). However, it is assumed that MDHAR is an important determinant of the changes in AsA level under stress (Ioannidi et al., 2009). In particular, the MDHAR activity considerably elevates the AsA content in fruits in the case of cold (Li et al., 2013) and oxidative (Gest et al., 2013) stresses.

The role of MDHAR in the increase of AsA content has been unambiguously demonstrated for tomatoes by QTL mapping (Sauvage et al., 2014) and by expression and enzyme activity profiling during fruit ripening (Mellidou et al., 2012). Expression of this gene also correlates with the vitamin $C$ accumulation in blueberries (Liu et al., 2015). The suppression of MDHAR in tomato fruits decreases the AsA content, thereby suggesting that the recycling control via an increase in MDHAR activity may be an efficient way for increasing the vitamin C content (Truffault et al., 2017). Moreover, it has been shown using siRNA that a decrease in this enzyme activity makes tomato plants unable to resist cold stress (El Airaj et al., 2013).

Expression of the DHAR gene correlates with the AsA accumulation in the chestnut rose (Huang et al., 2014) and blueberry (Liu et al., 2015) fruits.

Three paralogous genes - DHAR1, DHAR2, and DHAR3are known in plants. The paralogous genes display a low degree of homology. The DHARl gene has a length of approximately $6000 \mathrm{bp}$ and comprises six exons and five introns.

Among the horticultural crops, DHAR genes are known in the grape vine ( $V$. vinifera), tomato ( $S$. lycopersicum), sweet cherry ( $P$. avium), pepper (C. annuum), and apple (M. domestica).

The MDHAR paralogs also display a low degree of homology. The number of exons in these genes varies from nine to 17 . These genes have been found in the tomato (S. lycopersicum), arabidopsis (A. thaliana), and pepper (C. annuum)

Thus, the activities of the enzymes involved in AsA recycling needs further studies, the more so since the enzymes of this pathway may be directly associated with the resistance 
to cold and oxidative stress, which has an important applied value.

\section{Conclusion}

This paper briefs the main pathways of L-AsA biosynthesis and recycling in plant tissues. The key genes involved in the AsA biosynthesis and accumulation in fruits are considered. A huge volume of data on this issue demonstrates that the most significant role in the AsA biosynthesis, accumulation, and recycling is played by a synergistic interaction of all these components. Most likely, the insight into these interactions will form the background for the research into the vitamin $\mathrm{C}$ metabolism in plants during the next decade.

\section{References}

Agius F., Gonzalez-Lamothe R., Caballero J., Munoz-Blanco J., Botella M., Valpuesta V. Engineering increased vitamin C levels in plants by overexpression of a D-galacturonic acid reductase. NatBiotechnol. 2003;21:177-181. DOI 10.1038/nbt777.

Akram N., Shafiq F., Ashraf M. Ascorbic acid - a potential oxidant scavenger and its role in plant development and abiotic stress tolerance. Front. Plant Sci. 2017;8:613. DOI 10.3389/ fpls.2017.00613.

Alhagdow M., Mounet F., Gilbert L., Nunes-Nesi A., Garcia V., Just D., Petit J., Beauvoit B., Fernie A.R., Rothan C., Baldet P. Silencing of the mitochondrial ascorbate synthesizing enzyme L-galactono-1,4-lactone dehydrogenase affects plant and fruit development in tomato. Plant Physiol. 2007;145:1408-1422. DOI 10.1104/pp.107.106500.

Alós E., Rodrigo M.J., Zacarías L. Differential transcriptional regulation of L-ascorbic acid content in peel and pulp of citrus fruits during development and maturation. Planta. 2014;239:11131128. DOI 10.1007/s00425-014-2044-z.

Badejo A.A., Wada K., Gao Y.S., Maruta T., Sawa Y., Shigeoka S., Ishikawa T. Translocation and the alternative D-galacturonate pathway contribute to increasing the ascorbate level in ripening tomato fruits together with the D-mannose/L-galactose pathway. J. Exp. Bot. 2012;63:229-239. DOI 10.1093/jxb/err275.

Baydoun E.A.H., Fry S.C. $\left[2-{ }^{3}\right.$ H]Mannose incorporation in cultured plant cells: investigation of L-galactose residues of the primary cell wall. J. Plant Physiol. 1988;132:484-490. DOI 10.1016/S0176-1617(88)80068-3.

Bulley S.M., Rassam M., Hoser D., Otto W., Schünemann N., Wright M., MacRae E., Gleave A., Laing W. Gene expression studies in kiwifruit and gene over-expression in Arabidopsis indicates that GDP-L-galactose guanyltransferase is a major control point of vitamin C biosynthesis. J. Exp. Bot. 2009;60(3):765778. DOI 10.1093/jxb/ern327.

Bulley S., Wright M., Rommens C., Yan H., Rassam M., LinWang K., Andre C., Brewster D., Karunairetnam S., Allan A.C., Laing W.A. Enhancing ascorbate in fruits and tubers through over-expression of the L-galactose pathway gene GDP-L-galactose phosphorylase. Plant Biotechnol. J. 2012;10:390-397. DOI 10.1111/j.1467-7652. 2011.00668.x.

Cholet C., Claverol S., Claisse O., Rabot A., Osowsky A., Dumot V., Ferrari G., Gény L. Tartaric acid pathways in Vitis vinifera L. (cv. Ugni blanc): a comparative study of two vintages with contrasted climatic conditions. BMC Plant Biol. 2016;16:144. DOI 10.1186/s12870-016-0833-1.

Conklin P.L., Gatzek S., Wheeler G.L., Dowdle J., Raymond M.J., Rolinski S., Isupov M., Littlechild J.A., Smirnoff N. Arabidopsis thaliana VTC4 encodes L-galactose-1-P phosphatase, a plant ascorbic acid biosynthetic enzyme. J. Biol. Chem. 2006;281:15662-15670. DOI 10.1074/jbc.M601409200.

Conklin P.L., Norris S.R., Wheeler G., Williams E.H., Smirnoff N., Last R.L. Genetic evidence for the role of GDP-mannose in plant ascorbic acid (vitamin C) biosynthesis. Proc. Natl. Acad. Sci. USA. 1999;96:4198-4203. DOI 10.1073/pnas.96.7.4198.

Cruz-Rus E., Amaya I., Sanchez-Sevilla J.F., Botella M.A., Valpuesta V. Regulation of L-ascorbic acid content in strawberry fruits. J. Exp. Bot. 2011;62:4191-4201. DOI 10.1093/jxb/ err122.

Cruz-Rus E., Botella M.A., Valpuesta V., Gomez-Jimenez M.C. Analysis of genes involved in L-ascorbic acid biosynthesis during growth and ripening of grape berries. J. Plant Physiol. 2010;167:739-748. DOI 10.1016/j.jplph.2009.12.017.

Davey M.W., Gilot C., Persiau G., Østergaard J., Han Y., Bauw G.C., Van Montagu M.C. Ascorbate biosynthesis in Arabidopsis cell suspension culture. Plant Physiol. 1999;121:535-543. DOI 10.1104/pp.121.2.535.

Davey M.W., Van Montagu M., Inze D., Sanmartin M., Kanellis A., Smirnoff N., Benzie I.J.J., Strain J.J., Favell D., Fletcher J. Plant L-ascorbic acid: chemistry, function, metabolism, bioavailability and effects of processing. J. Sci. Food Agric. 2000;80:825-860. DOI $10.1002 /($ SICI) 1097-0010(20000515)80:7<825::AID-JSFA598> 3.0.CO;2-6.

Di Matteo A., Sacco A., Anacleria M., Pezzotti M., Delledonne M., Ferrarini A., Frusciante L., Barone A. The ascorbic acid content of tomato fruits is associated with the expression of genes involved in pectin degradation. BMC Plant. Biol. 2010;10:163. DOI 10.1186/ 1471-2229-10-163.

Diplock A.T., Charleux J.L., Crozier-Willi G., Kok F.J., Rice-Evans C., Roberfroid M., Stahl W., Vina-Ribes J. Functional food science and defence againstreactive oxidative species. Br. J. Nutr. 1998;80:77-112. DOI 10.1079/BJN19980106.

do Nascimento J.R.O., Higuchi B.K., Gomez M.L.P.A., Oshiro R.A., Lajolo F.M. L-ascorbate biosynthesis in strawberries: L-galactono-1,4-lactone dehydrogenase expression during fruit development and ripening. Postharvest Biol. Technol. 2005;38:34-42. DOI 10.1016/j.postharvbio.2005.05.014.

Dowdle J., Ishikawa T., Gatzek S., Rolinski S., Smirnoff N. Two genes in Arabidopsis thaliana encoding GDP-L-galactose phosphorylase are required for ascorbate biosynthesis and seedling viability. Plant J. 2007;52:673-689. DOI 10.1111/j.1365-313X.2007. 03266.x.

El Airaj H., Gest N., Truffaul V., Garchery C., Riqueau G., Gouble B., Page D., Stevens R. Decreased monodehydroascorbate reductase activity reduces tolerance to cold storage in tomato and affects fruit antioxidant levels. Postharvest Biol. Technol. 2013;86:502-510. DOI 10.1016/j.postharvbio.2013.07.035.

Figueroa-Méndez R., Rivas-Arancibia S. Vitamin C in health and disease: its role in the metabolism of cells and redox state in the brain. Front. Physiol. 2015;6:397. DOI 10.3389/ fphys.2015.00397.

Gatzek S., Wheeler G.L., Smirnoff N. Antisense suppression of L-galactose dehydrogenase in Arabidopsis thaliana provides evidence for its role in ascorbate synthesis and reveals light modulated L-galactose synthesis. Plant J. 2002;30(5):541-553. DOI 10.1046/j.1365-313X.2002.01315.x.

Gest N., Garchery C., Gautier H., Jiménez A., Stevens R. Lightdependent regulation of ascorbate in tomato by a monodehydroascorbate reductase localized in peroxisomes and the cytosol. Plant Biotechnol. J. 2013;11:344-354. DOI 10.1111/pbi.12020.

Gilbert L., Alhagdow M., Nunes-Nesi A., Quemener B., Guillon F., Bouchet B., Faurobert M., Gouble B., Page D., Garcia V., Petit J., 
Stevens R., Causse M., Fernie A.R., Lahaye M., Rothan C., Baldet P. GDP-D-mannose 3,5-epimerase (GME) plays a key role at the intersection of ascorbate and non-cellulosic cell-wall biosynthesis in tomato. Plant J. 2009;60:499-508. DOI 10.1111/j.1365313X.2009.03972.x.

Hancock R.D., Walker P.G., Pont S.D.A., Marquis N., Vivera S., Gordon S.L., Brennan R.M., Viola R. L-Ascorbic acid accumulation in fruit of Ribes nigrum occurs by in situ biosynthesis via the L-galactose pathway. Funct. Plant Biol. 2007;34:1080-1091. DOI 10.1071/FP07221.

Huang M., Xu Q., Deng X.X. L-Ascorbic acid metabolism during fruit development in an ascorbate-rich fruit crop chestnut rose (Rosa roxburghii Tratt). J. Plant Physiol. 2014;171(14):12051216. DOI 10.1016/j. jplph.2014.03.010.

Huang W., Qing G., Zhang H., Wu J., Zhang S. Distribution and metabolism of ascorbic acid in pear fruit (Pyrus pyrifolia Nakai cv. Aikansui). Afr. J. Biotechnol. 2013;12:1952-1961. DOI 10.5897/AJB11.4048.

Imai T., Ban Y., Terakami S., Yamamoto T., Moriguchi T. L-ascorbate biosynthesis in peach: cloning of six L-galactose pathway-related genes and their expression during peach fruit development. Physiol. Plant. 2009;136:139-149. DOI 10.1111/j.1399-3054.2009. 01213.x.

Imai T., Karita S., Shiratori G., Hattori M., Nunome T., Oba K., Hirai M. L-galactono- $\gamma$-lactone dehydrogenase from sweet potato: purification and cDNA sequence analysis. Plant Cell Physiol. 1998;39:1350-1358. DOI 10.1093/oxfordjournals. pcp.a029341.

Ioannidi E., Kalamaki M.S., Engineer C., Pateraki I., Alexandrou D., Mellidou I., Giovannonni J., Kanellis A.K. Expression profiling of ascorbic acid-related genes during tomato fruit development and ripening and in response to stress conditions. J. Exp. Bot. 2009;60:663-678. DOI 10.1093/jxb/ern322.

Iqbal Y., Ihsanullah I., Shaheen N., Hussain I. Significance of vitamin C in plants. J. Chem. Soc. Pakistan. 2009;31:169-170.

Jain A.K., Nessler C.L. Metabolic engineering of an alternative pathway for ascorbic acid biosynthesis in plants. Mol. Breed. 2000;6(1): 73-78. DOI 10.1023/A:1009680818138.

Keller R., Springer F., Renz A., Kossmann J. Antisense inhibition of the GDP-mannose pyrophosphorylase reduces the ascorbate content in transgenic plants leading to developmental changes during senescence. Plant J. 1999;91:131-141. DOI 10.1046/j.1365-313X.1999.00507.x.

Laing W.A., Frearson N., Bulley S., MacRae E. Kiwifruit L-galactose dehydrogenase: molecular, biochemical and physiological aspects of the enzyme. Funct. Plant Biol. 2004;31:1015-1025. DOI 10.1071/FP04090.

Laing W.A., Martinez-Sanchez M., Wright M.A., Bulley S.M., Brewster D., Dare A.P., Rassam M., Wang D., Storey R., Macknight R.C., Hellens R.P. An upstream open reading frame is essential for feedback regulation of ascorbate biosynthesis in Arabidopsis. Plant Cell. 2015;27:772-786. DOI 10.1105/ tpc.114.133777.

Laing W.A., Wright M.A., Cooney J., Bulley S.M. The missing step of the L-galactose pathway of ascorbate biosynthesis in plants, an L-galactose guanyltransferase, increases leaf ascorbate content. Proc. Natl. Acad. Sci. USA. 2007;104:9534-9539. DOI 10.1073/pnas.0701625104

Leferink N.G., van den Berg W.A., van Berkel W.J. L-Galactono$\gamma$-lactone dehydrogenase from Arabidopsis thaliana, a flavoprotein involved in vitamin C biosynthesis. FEBS J. 2008;275:713726. DOI 10.1111/j.1742-4658.2007.06233.x.
Li J., Li M., Liang D., Cui M., Ma F. Expression patterns and promoter characteristics of the gene encoding Actinidia deliciosa L-galactose-1-phosphate phosphatase involved in the response to light and abiotic stresses. Mol. Biol. Rep. 2013;40:1473-1485. DOI 10.1007/s11033-012-2190-y.

Li M., Chen X., Wang P., Ma F. Ascorbic acid accumulation and expression of genes involved in its biosynthesis and recycling in developing apple fruit. J. Am. Soc. Hortic. Sci. 2011;136:231-238.

Li M., Ma F., Liang D., Li J., Wang Y. Ascorbate biosynthesis during early fruit development is the main reason for its accumulation in kiwi. PLoS One. 2010;5(12):e14281. DOI 10.1371/journal.pone.0014281.

Li M.J., Ma F.W., Zhang M., Pu F. Distribution and metabolism of ascorbic acid in apple fruits (Malus domestica Borkh cv. Gala). Plant Sci. 2008;174:606-612. DOI 10.1016/j. plantsci.2008.03.008.

Liang D., Zhu T., Ni Z., Lin L., Tang Y., Wang Z., Wang X., Wang J., Lv X., Xia H. Ascorbic acid metabolism during sweet cherry (Prunus avium) fruit development. PLoS One. 2017;12(2):e0172818. DOI 10.1371/journal.pone.0172818.

Linster C.L., Adler L.N., Webb K., Christensen K.C., Brenner C., Clarke S.G. A second GDP-L-galactose phosphorylase in Arabidopsis en route to vitamin C: covalent intermediate and substrate requirements for the conserved reaction. J. Biol. Chem. 2008;283:18483-18492. DOI 10.1074/jbc.M802594200.

Linster C.L., Gomez T.A., Christensen K.C., Adler L.N., Young B.D., Brenner C., Clarke S.G. Arabidopsis VTC2 encodes a GDP-L-galactose phosphorylase, the last unknown enzyme in the Smirnoff-Wheeler pathway to ascorbic acid in plants. J. Biol. Chem. 2007; 282:18879-18885. DOI 10.1074/ jbc.M702094200.

Liu F., Wang L., Gu L., Zhao W., Su H., Cheng X. Higher transcription levels in ascorbic acid biosynthetic and recycling genes were associated with higher ascorbic acid accumulation in blueberry. Food Chem. 2015;188:399-405. DOI 10.1016/j.foodchem.2015. 05.036 .

Loewus F.A. Biosynthesis and metabolism of ascorbic acid in plants and of analogs of ascorbic acid in fungi. Phytochemistry. 1999;52: 193-210. DOI 10.1016/S0031-9422(99)00145-4.

Loewus F.A., Kelly S. The metabolism of D-galacturonic acid and its methyl ester in the detached ripening strawberry. Arch. Biochem. Biophys. 1961;95:483-493. DOI 10.1016/00039861(61)90180-1.

Loewus F.A., Loewus M.W. Biosynthesis and metabolism of ascorbic acid in plants. Crit. Rev. Plant Sci. 1987;5:101-119. DOI 10.1080/07352688709382235.

LorenceA., Chevone B.I., Mendes P., Nessler C.L. Myo-inositol oxygenase offers a possible entry point into plant ascorbate biosynthesis. Plant Physiol. 2004;134:1200-1205. DOI 10.1104/pp.103. 033936.

Lukowitz W., Nickle T.C., Meinke D.W., Last R.L., Conklin P.L., Somerville C.R. Arabidopsis cyt 1 mutants are deficient in a mannose-1-phosphate guanylyltransferase and point to a requirement of N-linked glycosylation for cellulose biosynthesis. Proc. Natl. Acad. Sci. USA. 2001;98(5):2262-2267. DOI 10.1073/ pnas.051625798.

Maruta T., Ichikawa Y., Mieda T., Takeda T., Tamoi M., Yabuta Y., Ishikawa T., Shigeoka S. The contribution of Arabidopsis homologs of L-gulono-1,4-lactone oxidase to the biosynthesis of ascorbic acid. Biosci. Biotechnol. Biochem. 2010;74:14941497. DOI 10.1271/bbb.100157. 
Mellidou I., Chagné D., Laing W., Keulemans J., Davey M.W. Allelic variation in paralogs of GDP-L-galactose phosphorylase is a major determinant of vitamin $\mathrm{C}$ concentrations in apple fruit. Plant Physiol. 2012;160:1613-1629. DOI 10.1104/ pp.112.203786.

Mellidou I., Kanellis A.K. Genetic control of ascorbic acid biosynthesis and recycling in horticultural crops. Front. Chem. 2017;5:50. DOI 10.3389/fchem.2017.00050.

Michell R.H. Evolution of the diverse biological roles of inositols. Biochem. Soc. Symp. 2007;74:223-246. DOI 10.1042/ BSS0740223.

Mieda T., Yabuta Y., Rapolu M., Motoki T., Takeda T., Yoshimura K., Ishikawa T., Shigeoka S. Feedback inhibition of spinach L-galactose dehydrogenase by L-ascorbate. Plant Cell Physiol. 2004;45:1271-1279. DOI 10.1093/pcp/pch152.

Mounet-Gilbert L., Dumont M., Ferrand C., Bournonville C., Monier A., Jorly J., Lemaire-Chamley M., Mori K., Atienza I., Hernould M., Stevens R., Lehner A., Mollet J.C., Rothan C., Lerouge P., Baldet P. Two tomato GDP-D-mannose epimerase isoforms involved in ascorbate biosynthesis play specific roles in cell wall biosynthesis and development. J. Exp. Bot. 2016;67:4767-4777. DOI 10.1093/jxb/erw260.

Mutsuda M., Ishikawa T., Takeda T., Shigeoka S. Subcellular-localization and properties of L-galactono- $\gamma$-lactone dehydrogenase in spinach leaves. Biosci. Biotechnol. Biochem. 1995;59:19831984. DOI 10.1271/bbb.59.1983.

Nishikimi M., Yagi K. Biochemistry and Molecular Biology of Ascorbic Acid Biosynthesis. In: Harris J.R. (Ed.). Subcellular Biochemistry (Ascorbic Acid: Biochemistry and Biochemical Cell Biology). Springer, Boston, MA, 1996;25:17-39. DOI 10.1007/978-1-4613-0325-1_2.

Oesterhelt C., Schnarrenberger C., Gross W. The reaction mechanism of phosphomannomutase in plants. FEBS Lett. 1997;401:35-37. DOI 10.1016/S0014-5793(96)01425-1.

Pastori G.M., Kiddle G., Antoniw J., Bernard S., Veljovic-Jovanovic S., Verrier P.J., Noctor G., Foyer C.H. Leaf vitamin C contents modulate plant defense transcripts and regulate genes that control development through hormone signaling. Plant Cell. 2003;15:939-951. DOI 10.1105/tpc.010538.

Pateraki I., Sanmartin M., Kalamaki M.S., Gerasopoulos B., Kanellis A.K. Molecular characterization and expression studies during melon fruit development and ripening of L-galactono-1,4lactone dehydrogenase. J. Exp. Bot. 2004;55:1623-1633. DOI 10.1093/jxb/erh186.

Radzio J.A., Lorence A., Chevone B.I., Nessler C.L. L-Gulono-1,4lactone oxidase expression rescues vitamin C-deficient Arabidopsis (vtc) mutants. Plant Mol. Biol. 2003;53(6):837-844. DOI 10.1023/B:PLAN.0000023671.99451.1d.

Roberts R.M. The metabolism of D-mannose- ${ }^{14} \mathrm{C}$ to polysaccharide in corn roots. Specific labelling of L-galactose, D-mannose, and L- fucose. Arch. Biochem. Biophys. 1971;145:685-692. DOI 10.1016/S0003-9861(71)80029-2.

Rodríguez-Ruiz M., Mateos R.M., Codesido V., Corpas F.J., Palma J.M. Characterization of the galactono-1,4-lactone dehydrogenase from pepper fruits and its modulation in the ascorbate biosynthesis. Role of nitric oxide. Redox Biol. 2017;12:171-181. DOI 10.1016/j.redox. 2017.02.009.

Sauvage C., Segura V., Bauchet G., Stevens R., Do P.T., Nikoloski Z., Fernie A.R., Causse M. Genome-wide association in tomato reveals 44 candidate loci for fruit metabolic traits. Plant Physiol. 2014;165: 1120-1132. DOI 10.1104/pp.114.241521.
Shigeoka S., Nakano Y., Kitaoka S. The biosynthetic pathway of L-ascorbic acid in Euglena gracilis z. J. Nutr. Sci. Vitaminol. 1979;25: 299-307. DOI 10.3177/jnsv.25.299.

Smirnoff N. Ascorbic acid metabolism and functions: a comparison of plants and mammals. Free Radic. Biol. Med. 2018;122:116129. DOI 10.1016/j.freeradbiomed.2018.03.033.

Streltsina S.A., Burmistrov L.A., Nikitina E.V. Nutritious and biologically active substances of mountain ash fruits (Sorbus L.) in the conditions of the northwestern zone of horticulture in Russia. Agrarnaya Rossiya = Agricultural Russia. 2010;3:10-17. (in Russian)

Suekawa M., Kondo T., Fujikawa Y., Esaka M. Regulation of Ascorbic Acid Biosynthesis in Plants. In: Hossain M.A. et al. (Eds.). Ascorbic Acid in Plant Growth, Development and Stress Tolerance. Springer, 2017;157-176. DOI 10.1007/978-3-31974057-7 6.

Torabinejad J., Donahue J.L., Gunesekera B.N., Allen-Daniels M.J., Gillaspy G.E. VTC4 is a bifunctional enzyme that affects myoinositol and ascorbate biosynthesis in plants. Plant Physiol. 2009;150: 951-961. DOI 10.1104/pp.108.135129.

Truffault V., Fry S.C., Stevens R.G., Gautier H. Ascorbate degradation in tomato leads to accumulation of oxalate, threonate and oxalyl threonate. Plant J. 2017;89(5):996-1008. DOI 10.1111/ tpj.13439.

Walker P.G., Viola R., Woodhead M., Jorgensen L., Gordon S., Brennan R., Hancock R. Ascorbic acid content of blackcurrant fruit is influenced by both genetic and environmental factors. Func. Plant Sci. Biotech. 2010;1:40-52.

Wang L.Y., Meng X., Yang D.Y., Wang G.D., Meng Q.W. Overexpression of tomato GDP-L-galactose phosphorylase gene in tobacco improves tolerance to chilling stress. Plant Cell Rep. 2014;33(9): 1441e1451. DOI 10.1007/s00299-014-1627-2.

Watanabe K., Suzuki K., Kitamura S. Characterization of a GDP-D-mannose 3",5"-epimerase from rice. Phytochemistry. 2006;67:338-346. DOI 10.1016/j.phytochem.2005.12.003.

Wheeler G.L., Jones M.A., Smirnoff N. The biosynthetic pathway of vitamin C in higher plants. Nature. 1998;393:365-369. DOI 10.1038/30728.

Wolucka B.A., Persiau G., Van Doorsselaere J., Davey M.W., Demol H., Vandekerckhove J., Van Montagu M., Zabeau M., Boerjan W. Partial purification and identification of GDP-mannose 3",5"-epimerase of Arabidopsis thaliana, a key enzyme of the plant vitamin C pathway. Proc. Natl. Acad. Sci. USA. 2001;98:14843-14848. DOI 10.1073/pnas.011578198.

Wolucka B.A., Van Montagu M. GDP-mannos 3,5-epimerase forms GDP-L-gulose, a putative intermediate for the de novo biosynthesis of vitamin C in plants. J. Biol. Chem. 2003;278:4748347490. DOI 10.1074/jbc.M309135200.

Xu Q., Chen L., Ruan X., ... Nagarajan N., Deng X., Ruan Y. The draft genome of sweet orange (Citrus sinensis). Nat. Genet. 2013;45:59-66. DOI 10.1038/ng.2472.

Yabuta Y., Yoshimura K., Takeda T., Shigeoka S. Molecular characterization of tobacco mitochondrial L-galactono- $\gamma$-lactone dehydrogenase and its expression in Escherichia coli. Plant Cell Physiol. 2000;41:666-675. DOI 10.1093/pcp/41.6.666.

Yang X.Y., Xie J.X., Wang F.F., Zhong J., Liu Y.Z., Li G.H., Peng S.A. Comparison of ascorbate metabolism in fruits of two citrus species with obvious difference in ascorbate content in pulp. J. Plant Physiol. 2011;168:2196-2205. DOI 10.1016/j. jplph.2011. 07.015.

Yoshimura K., Nakane T., Kume S., Shiomi Y., Maruta T., Ishikawa T., Shigeoka S. Transient expression analysis revealed the 
importance of $V T C 2$ expression level in light/dark regulation of ascorbate biosynthesis in Arabidopsis. Biosci. Biotechnol. Biochem. 2014;78:60-66. DOI 10.1080/09168451.2014.877831. Zhang C.J., Liu J.X., Zhang Y.Y., Cai X.F., Gong P.J., Zhang J.H., Wang T.T., Li H.X., Ye Z.B. Overexpression of SlGMEs leads to ascorbate accumulation with enhanced oxidative stress, cold, and salt tolerance in tomato. Plant Cell Rep. 2011;30:389-398. DOI 10.1007/s00299-010-0939-0.
Zhang Y.Y., Li H.X., Shu W.B., Zhang C.J., Zhang W., Ye Z.B. Suppressed expression of ascorbate oxidase gene promotes ascorbic acid accumulation in tomato fruit. Plant Mol. Biol. Rep. 2011;29:638-645. DOI 10.1007/s11105-010-0271-4.

Zhou Y., Tao Q.C., Wang Z.N., Fan R., Li Y., Sun X.F., Tang K.X. Engineering ascorbic acid biosynthetic pathway in Arabidopsis leaves by single and double gene transformation. Biol. Plant. 2012;56:451-457. DOI 10.1007/s10535-012-0119-x.

ORCID ID

E.Z. Kochieva orcid.org/0000-0002-6091-0765

Acknowledgements. This work was partially supported by grants from the Russian Foundation for Basic Research (\#18-316-00033) and the Ministry of Science and Higher Education of the Russian Federation.

Conflict of interest. The authors declare no conflict of interest.

Received September 13, 2018. Revised November 24, 2018. Accepted November 25, 2018. 